\title{
PENGARUH PEMBERIAN EKSTRAK ETANOL DAUN BAWANG MEKAH (Eleutherine Americana Merr.) TERHADAP KADAR MALONDIALDEHYDE TIKUS WISTAR (Rattus norvegicus) JANTAN PASCA PAPARAN ASAP ROKOK
}

\author{
Melda Mery Andiriyani ${ }^{1, *)}$, Eka Kartika Untari' ${ }^{2}$, Sri Wahdaningsih ${ }^{3}$ \\ 1. Program Studi Farmasi, Fakultas Kedokteran, Universitas Tanjungpura \\ 2. Bagian Farmakologi Farmasi, Fakultas Kedokteran, Universitas Tanjungpura \\ ${ }^{3 .}$ Bagian Biologi Farmasi, Fakultas Kedokteran, Universitas Tanjungpura
}

\begin{abstract}
Malondialdehyde (MDA) is a biomarker of lipid peroxidation that is closely correlated with level of oxidative stress. The aim of this study was to know ethanol extract activities from E.americana leaves against blood plasma MDA in male Wistar rats exposed by cigarette smoke using tiobarbituric acid test. The simplicia extracted by maseration using $70 \%$ ethanol. Twenty four rats were divided into six groups, i.e. : a normal group, an exposed cigarette smoke (negative) control group, a positive control group and three treatment groups. One normal group received carboxyl methyl cellulose and another groups exposed cigarette smoke during 14 days. Positive control group received vitamin $E(18 \mathrm{mg} / \mathrm{kg} \mathrm{BW})$, and another groups received ethanol extract of E.americana leaves doses 180; 90; $45 \mathrm{mg} / \mathrm{kg} B \mathrm{~W}$, respectively. The MDA level was analysed by spectrophotometer UV-Visible in 532,2 $\mathrm{nm}$. The MDA level statically analysis by Kruskal-Wallis test and following by Mann-Whitney test. The mean MDA levels of normal group, negative control group, positive control group and groups received ethanol extract of E.americana leaves doses 180; 90; $45 \mathrm{mg} / \mathrm{kg} \mathrm{BW}$ were 0,11 $\pm 0,09 ; 13,74 \pm 2,84 ; 0,06 \pm 0,03 ; 10,88 \pm 2,19 ; 0,13 \pm 0,03 ; 0,03 \pm 0,02 \mathrm{ppm}$. The mean MDA levels of groups received ethanol extract of E.americana leaves doses at 180; $90 \mathrm{mg} / \mathrm{kg} B W$ significantly $(p<0,05)$ lower than negative control group. These results show the beneficial effect of ethanol extract of E.americana leaves in the MDA level reducing on the rats that exposed by cigarette.
\end{abstract}

Key words: Eleutherine americana, cigarette smoke, MDA

\section{PENDAHULUAN \\ Latar Belakang}

Indonesia merupakan negara ketiga yang memiliki jumlah perokok aktif terbanyak di dunia yaitu 61,4 juta perokok setelah Cina dan India. Sebanyak 67 persen pria dan 4,5 persen wanita di Indonesia adalah perokok. Tingginya jumlah perokok aktif berbanding lurus dengan jumlah perokok pasif yang terpapar asap rokok (secondhand smoke). Jumlah penduduk Indonesia yang menjadi perokok pasif lebih dari 97 juta jiwa ${ }^{1}$.

Asap rokok merupakan salah satu sumber radikal bebas. Radikal bebas dihasilkan akibat pembakaran tidak sempurna ${ }^{2}$. Paparan rokok dapat mengakibatkan kardiomiopati dan reaksi imun di dalam hati ${ }^{3}$. Rokok juga dapat mempengaruhi penurunan antioksidan pada serum yang memicu terjadinya stres oksidatif ${ }^{4}$.

Salah satu indikator yang dipakai untuk menentukan stres oksidatif pada manusia adalah kadar MDA yang merupakan hasil peroksidasi lipid di dalam tubuh akibat radikal bebas ${ }^{5,6}$. Peningkatan kadar MDA dapat terjadi akibat adanya paparan asap rokok ${ }^{7}$. Terdapat hubungan antara lama pemaparan rokok kretek dengan peningkatan kadar MDA ${ }^{8}$.
Antioksidan adalah suatu senyawa yang dapat digunakan untuk mengatasi kerusakan oksidatif akibat radikal bebas atau senyawa oksigen reaktif (Reactive Oxygen Species) ${ }^{9}$. Tanaman E.americana yang termasuk famili Iridaceae memiliki potensi antioksidan. Ekstrak etanol bulbus E.americana memiliki efek antioksidan terhadap gambaran histopatologi paru-paru tikus yang terpapar asap rokok ${ }^{10}$. Hasil penelitian lain menunjukkan bahwa ekstrak etanol $70 \%$ daun E.americana yang diuji menggunakan metode DPPH memiliki efek antioksidan yang sangat aktif dengan nilai $\mathrm{IC}_{50}$ sebesar $31,97437 \mu \mathrm{g} / \mathrm{mL}{ }^{11}$. Fraksi etanol $70 \%$ daun E.americana juga memiliki efek antioksidan setelah dilakukan pengujian secara in vitro menggunakan metode DPPH dengan nilai $\mathrm{IC}_{50} 35,5468 \mathrm{~g} / \mathrm{mL}^{12}$.

Penjelasan di atas menjadi dasar dilakukannya pengujian aktivitas antioksidan dari ekstrak etanol daun E.americana secara in vivo pada tikus jantan. Pengujian ini dilakukan dengan pengukuran kadar MDA tikus wistar jantan setelah paparan asap rokok dan pemberian ekstrak etanol $70 \%$ daun $E$. americana. 


\section{METODOLOGI PENELITIAN}

A. Alat

Alat yang digunakan adalah rotary evaporator (Heodolph), oven (Memmert), timbangan analitik (Precisa), desikator, alat-alat gelas (Pyrex Iwaki), cawan krusibel, bejana maserasi, botol semprot, mikropipet (Rainin E1019705K), blood tube, sonde oral, hot plate (Schott Instrument $($ )), blender, spot test, spektrofotometer UV-Vis (Shimadzu MR 2500), Vortex (Barnstead M37610), blue tip, pisau scalpel, kandang hewan uji, vortex, sentrifuge, shaker, smoking chamber berukuran $38,5 \times 28,5 \times 22,5 \mathrm{~cm}$ dan spoit 3cc.

\section{B. Bahan}

Bahan yang adalah simplisia daun E.americana, vitamin E, etanol 70\%, serbuk magnesium, larutan $\mathrm{HCl} 2 \mathrm{~N}, \mathrm{HCl}$ pekat, larutan $\mathrm{FeCl}_{3} 5 \%, \mathrm{H}_{2} \mathrm{SO}_{4} 2 \mathrm{~N}, \mathrm{H}_{2} \mathrm{SO}_{4}$ pekat, pereaksi Dragendorff, pereaksi Wagner, pereaksi Mayer, akuades, aluminium foil, kertas saring, CMC (carboxy methyl cellulose), TBA (thiobarbituric acid) reagent, TCA (tri chloro acetate), TMP (tetramethoxypropane), asam asetat glasial, asam asetat anhidrat.

\section{Hewan Uji}

24 ekor tikus Wistar jantan.

\section{Tahap Penelitian}

\section{Determinasi Tanaman}

Determinasi tanaman E.americana dilakukan di Laboratorium Biologi Fakultas Matematika dan Ilmu Pengetahuan Alam Universitas Tanjungpura. Sampel yang diserahkan berupa tanaman utuh dariakar, daun dan umbi.

\section{Pembuatan Ekstrak}

Metode ekstraksi yang digunakan dalam penelitian ini adalah ekstraksi maserasi. Proses ekstraksi dilakukan terhadap daun E.americana yang telah dikeringkan (simplisia). Ekstraksi dilakukan selama 6x24 jam menggunakan pelarut etanol 70\%.

\section{Penetapan Susut Pengeringan}

Penetapan susut pengeringan adalah pengukuran sisa zat setelah pengeringan pada temperatur $105^{\circ} \mathrm{C}$ selama 30 menit atau sampai berat konstan yaitu tidak terjadi lagi perubahan bobot (tidak lebih dari 5\%). Penetapan susut pengeringan dilakukan secara triplo. Digunakan kurs porselen yang sebelumnya telah dipanaskan pada suhu $105^{\circ} \mathrm{C}$ dan ditimbang setiap 30 menit hingga diperoleh berat konstan setelah dua kali penimbangan. Ekstrak yang digunakan yaitu sebanyak 2,2570; 2,0400; 2,1514 g dan dimasukkan ke dalam kurs porselen. Kemudian ekstrak yang terdapat pada kurs porselen dimasukkan ke dalam oven. Selama dipanaskan penutup kurs porselen dibuka. Pemanasan dilakukan pada suhu $105^{\circ} \mathrm{C}$ dan ditimbang setiap 30 menit hingga bobot konstan setelah dua kali penimbangan. Setiap dilakukan penimbangan ekstrak terlebih dahulu dimasukkan ke dalam desikator selama 15 menit ${ }^{13}$.

\section{Skrining Fitokimia Pemeriksaan Alkaloid}

Larutan ekstrak ditambahkan kloroform dan amonia kemudian ditambahkan $1 \mathrm{~mL}$ asam sulfat 2 $\mathrm{N}$ dan dikocok sampai terbentuk dua lapisan. Lapisan asam (atas) dipipet dan dimasukkan ke dalam tiga buah tabung reaksi. Tabung reaksi pertama ditambahkan dua tetes pereaksi Mayer. Tabung reaksi kedua ditambahkan dua tetes pereaksi Dragendorf. Tabung reaksi ketiga ditambahkan dua tetes pereaksi Wagner. Adanya senyawa alkaloid ditandai dengan terbentuknya endapan putih pada tabung reaksi pertama dan timbulnya endapan berwarna coklat kemerahan pada tabung reaksi kedua dan ketiga ${ }^{14}$.

\section{Pemeriksaan Flavonoid}

Larutan ekstrak sebanyak $2 \mathrm{ml}$ ditambah dengan $0,5 \mathrm{~mL} \mathrm{HCl}$ pekat dan beberapa milig serbuk logam Mg. Adanya flavonoid ditandai dengan warna merah ${ }^{14}$.

\section{Pemeriksaan Saponin}

Ekstrak sebanyak $50 \mathrm{mg}$ dimasukkan ke dalam tabung reaksi, lalu ditambahkan dengan air $20 \mathrm{~mL}$ dan dikocok dengan kuat selama 15 menit. Hasil positif ditunjukkan dengan terbentuknya busa dengan tinggi $2 \mathrm{~cm}^{15}$.

\section{Pemeriksaan Triterpenoid dan Steroid}

Larutan ekstrak sebanyak $1 \mathrm{~mL}$ dikeringkan di atas papan spot test, ditambahkan tiga tetes $\mathrm{CH} 3 \mathrm{COOH}$ anhidrat dan satu tetes larutan $\mathrm{H} 2 \mathrm{SO} 4$ pekat. Warna berubah menjadi merah yang menunjukkan adanya senyawa triterpenoid dan warna berubah menjadi biru yang menunjukkan adanya senyawa steroid ${ }^{15}$. 


\section{Pemeriksaan Fenol}

Larutan ekstrak diteteskan di atas pelat tetes dan ditambah larutan $\mathrm{FeCl} 35 \%$. Hasil positif yaitu timbul warna biru kehitaman ${ }^{15}$.

\section{Pemeriksaan Tanin}

Larutan ekstrak ditambahkan larutan gelatin $1 \%$ dan larutan $\mathrm{NaCl} 10 \%$. Hasil positif ditandai dengan terbentuknya endapan putih ${ }^{15}$.

\section{Pengujian Aktivitas Antioksidan}

Pemaparan Asap Rokok dan Pemberian Ekstrak Etanol Daun E.americana

Rokok yang digunakan adalah rokok kretek tanpa filter. Tikus diberi paparan asap rokok sebanyak tiga batang rokok dalam satu hari. Proses pemaparan dilakukan pada pagi hari. Pemaparan dilakukan selama 14 hari. Satu jam setelah paparan tikus diberi ekstrak etanol daun E.americana peroral sesuai kelompok dosis dan berat badan tikus. Pemaparan asap rokok menggunakan smoking chamber ${ }^{16}$.

\section{Perlakuan Hewan Percobaan}

Penelitian ini dibagi menjadi enam kelompok sebagai berikut :

a. Kelompok normal

b. Kelompok kontrol negatif yang diberi paparan asap rokok.

c. Kelompok kontrol negatif yang diberi paparan asap rokok, kemudian diberi vitamin $\mathrm{E}$ dosis 18 $\mathrm{mg} / \mathrm{kg} \mathrm{BB}$.

d. Kelompok perlakuan yang diberi paparan asap rokok, kemudian diberi ekstrak etanol dosis 45 $\mathrm{mg} / \mathrm{kg} \mathrm{BB}$.

e. Kelompok perlakuan yang diberi paparan asap rokok, kemudian diberi ekstrak etanol dosis 90 $\mathrm{mg} / \mathrm{kg} \mathrm{BB}$.

f. Kelompok perlakuan yang diberi paparan asap rokok, kemudian diberi ekstrak etanol dosis 180 $\mathrm{mg} / \mathrm{kg} \mathrm{BB}$.

\section{Pengambilan Sampel Darah}

Tikus dipuasakan selama 24 jam. Tikus dibunuh dengan cara dislokasi leher. Darah diambil melalui jantung. Darah disentrifugasi pada kecepatan $3000 \mathrm{rpm}$ selama 10 menit. Plasma darah yang terletak pada bagian atas dipisahkan dan diambil untuk dianalisis konsentrasi MDA ${ }^{17}$.

\section{Analisis Konsentrasi MDA Plasma Pembuatan Kurva Standar Larutan stok pereaksi 1,1,3,3- tetrametoksipropana (TMP) konsentrasi $6 \quad$ M}

diencerkan menjadi 0,$9 ; 0,8 ; 0,7 ; 0,5 ; 0,4 ; 0,3 \mathrm{ppm}$. Setiap konsentrasi TMP direaksikan dengan $1,0 \mathrm{~mL}$ TCA $20 \%$ dan $1,0 \mathrm{~mL}$ TBA $1 \%$ dalam pelarut asam asetat glasial $50 \%$. Semua larutan kemudian diinkubasi selama 45 menit pada suhu $95^{\circ} \mathrm{C}$. Setelah didinginkan, larutan disentrifugasi pada kecepatan $1000 \mathrm{rpm}$ selama 15 menit. Supernatan pada lapisan atas diukur absorbansinya dengan menggunakan spektrofotometer UV-Vis pada panjang gelombang $532,2 \mathrm{~nm}^{17}$.

\section{Pengukuran Sampel}

Pengukuran konsentrasi dari sampel percobaan dilakukan dengan cara yang sama seperti larutan standar, yaitu $1,0 \mathrm{~mL}$ plasma darah direaksikan dengan $1,0 \mathrm{~mL}$ TCA $20 \%$ dan $1,0 \mathrm{~mL}$ TBA $1 \%$ dalam asam asetat glasial $50 \%$, kemudian diinkubasi selama 45 menit pada suhu $95^{\circ} \mathrm{C}$, kemudian dibiarkan dingin. Larutan disentrifugasi selama 15 menit pada kecepatan $1000 \mathrm{rpm}$. Supernatan dipisahkan kemudian diukur absorbansinya menggunakan spektrofotometer UV-Vis pada panjang gelombang 532,2 $\mathrm{nm}$. Konsentrasi sampel diperoleh dengan memplot data absorbansi sampel ke dalam kurva standar ${ }^{17}$.

\section{Analisis Data}

Data hasil skrining fitokimia disajikan secara kualitatif. Kadar MDA dan berat badan tikus yang diperoleh dinyatakan sebagai mean dan standar deviasi dari masing-masing kelompok $(\mathrm{n}=4)$. Analisis statistik dilakukan dengan menggunakan program komputer Statistical Program Service Solution (SPSS) versi 17 trial. Kadar MDA dengan ekstrak etanol daun E.americana dianalisis menggunakan uji non parametric yaitu uji KruskalWallis dan dilanjutkan dengan analisa menggunakan uji Mann-Whitney. Uji statistik dilakukan pada derajat kepercayaan $95 \%$.

\section{HASIL DAN PEMBAHASAN \\ 1. Determinasi Tanaman}

Determinasi tanaman dilakukan di Laboratorium Biologi, Fakultas Matematika dan Ilmu Pengetahuan Alam, Universitas Tanjungpura, Pontianak, Kalimantan Barat. Hasil determinasi tanaman menunjukkan bahwa sampel tanaman yang diidentifikasi adalah benar tanaman E.americana yang memiliki spesies Eleutherine americana Merr. berasal dari suku Iridaceae.

\section{Ekstraksi}

Hasil ekstrak kental yang diperoleh adalah 35,7 g dengan nilai rendemen $17,85 \%$. 


\section{Penetapan Susut Pengeringan}

Hasil penetapan diperoleh persentase susut pengeringan ekstrak sebesar 19,55\%. Ekstrak tersebut termasuk dalam rentang ekstrak kental yaitu $5-30 \%{ }^{13,18}$.

\section{Skrining Fitokimia}

Metode skrining fitokimia yang digunakan pada penelitian ini adalah uji tabung. Senyawa yang diidentifikasi yaitu alkaloid, flavonoid, saponin, triterpenoid dan steroid, fenol serta tanin. Hasil skrining dapat dilihat pada tabel 1.

Tebel 1. Hasil skrining fitokimia ekstrak etanol daun E.americana

\begin{tabular}{|l|c|}
\hline \multicolumn{1}{|c|}{ Metabolit Sekunder } & Keterangan \\
\hline Alkaloid & + \\
\hline Flavonoid & + \\
\hline Saponin & + \\
\hline Triterpenoid dan Steroid & + \\
\hline Fenol & + \\
\hline Tanin & - \\
\hline
\end{tabular}

Keterangan $:(+)=$ terdeteksi, $(-)=$ tidak terdeteksi

\section{Pengujian Aktivitas Antioksidan Perlakuan Hewan Uji}

Pengujian antioksidan yang dilakukan pada penelitian ini adalah uji secara in vivo. Hewan uji dikondisikan seperti perokok pasif yang terpapar asap rokok kretek tanpa filter. Jumlah rokok yang digunakan dalam satu hari yaitu tiga batang rokok. Penelitian Dewi et al. (2003) menyatakan bahwa kadar nikotin pada rokok memiliki kandungan yang lebih besar saat dilepaskan ke udara dibandingkan yang dihirup oleh perokok ${ }^{19}$. Pemaparan dilakukan pada pagi hari dijam yang sama. Pemaparan yang dilakukan pada pagi hari karena hewan tikus akan semakin agresif apabila semakin siang sehingga menyulitkan perlakuan dan dapat meningkatkkan stres pada hewan uji. Rokok dipaparkan secara akut selama 14 hari. Review jurnal yang dilakukan oleh Van et al. (2003) menyatakan bahwa banyak penelitian menggunakan paparan akut karena merupakan metode yang relatif mudah dan sensitif untuk mengetahui efek spesifik dari stres oksidatif.
Selain itu paparan akut dapat menyebabkan kerusakan jaringan akibat peningkatan peroksidasi lipid ${ }^{20}$.

\section{Pengambilan Sampel Darah}

Pengukuran kadar MDA dilakukan pada sampel darah hewan uji. Bagian darah yang diukur adalah plasma darah. Pengukuran pada plasma darah disebabkan oleh sebagian besar MDA pada darah terdapat di dalam plasma. Proses pengambilan plasma darah dilakukan dengan menambahkan antikoagulan yaitu EDTA sebelum dilakukan sentrifugasi. Sentrifugasi dilakukan untuk memisahkan supernatan dan platelet. Plasma darah terkandung pada supernatan yang dihasilkan ${ }^{21}$.

\section{Metode Pengukuran Kadar MDA}

Metode yang digunakan untuk mengukur kadar MDA adalah metode TBA. TBA mempunyai nilai kepekaan yang tinggi terhadap radikal bebas dan mudah diaplikasikan untuk sampel dalam berbagai tahap oksidasi. TBA akan bereaksi dengan gugus karboksilat dari MDA melalui penambahan nukleofilik membentuk kompleks MDA-TBA dalam suasana asam dan membentuk warna merah muda. Metode TBA menggunakan TCA 20\%, TBA $1 \%$ dan asam asetat glasial 50\%. TCA berfungsi untuk mengendapkan protein yang terdapat di dalam plasma, sedangkan TBA berfungsi sebagai pengikat MDA pada plasma. TBA akan bereaksi dengan MDA dalam konsidi asam pada suhu $95^{\circ} \mathrm{C}$. Oleh karena itu, dilakukan penambahan asam asetat glasial dan inkubasi sampel ${ }^{17,22}$.

\section{Penentuan Kurva Baku}

Pengukuran kadar MDA dilakukan dengan manggunakan alat spektrofotometer UV-Vis. Baku standar yang digunakan adalah TMP. TMP jika direaksikan dengan TBA akan membentuk MDA dan metanol sebagai hasil sampingan. Panjang gelombang maksimal optimasi yang dihasilkan dari penentuan kurva baku yaitu 532,2 nm. Hasil nilai $\mathrm{r}$ yang diperoleh yaitu 0,9930663438 . Persamaan kurva baku yang didapat yaitu $\mathrm{y}=0,8264285714 \mathrm{x}+$ 0,06580952381 . 


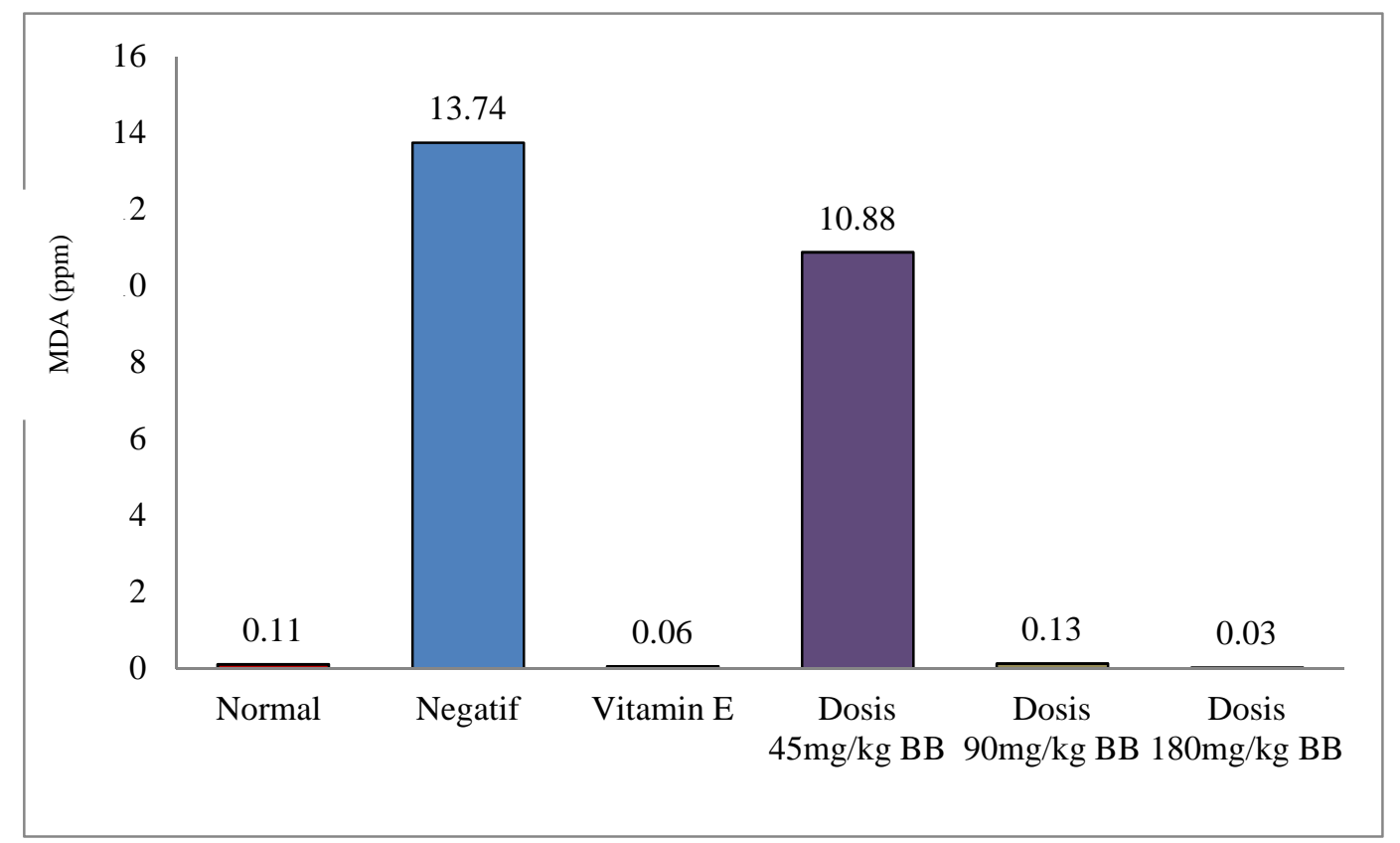

Gambar 1. Grafik Kadar MDA Plasma Tikus Wistar Jantan Pasca Paparan Asap Rokok

\section{Analisis Kadar MDA}

Kadar MDA yang diperoleh dianalisis menggunakan uji non parametrik. Kadar MDA dari keenam kelompok dianalisis menggunakan uji Kruskal-Wallis. Perbedaan kadar MDA antar masing-masing kelompok menggunakan uji MannWhitney. Hasil analisis kadar MDA dapat dilihat pada tabel 2.

Tabel 2. Hasil Analisis Uji Kruskal Wallis Kadar MDA Plasma Tikus Wistar Jantan Pasca Paparan Asap Rokok

\begin{tabular}{|c|c|c|}
\hline $\begin{array}{l}\text { Kelompok } \\
\text { Perlakuan }\end{array}$ & $\begin{array}{c}\mathrm{N}=4 \\
\text { mean } \pm \text { SD } \\
\text { MDA }(p p m)\end{array}$ & p-value \\
\hline Normal & $0,11 \pm 0,09$ & \multirow{6}{*}{$0,003^{*}$} \\
\hline Negatif & $13,74 \pm 2,84$ & \\
\hline Vitamin E & $0,06 \pm 0,03$ & \\
\hline $\begin{array}{c}\text { Dosis } 45 \mathrm{mg} / \mathrm{kg} \\
\text { BB }\end{array}$ & $10,88 \pm 2,19$ & \\
\hline $\begin{array}{c}\text { Dosis } 90 \mathrm{mg} / \mathrm{kg} \\
\text { BB }\end{array}$ & $0,13 \pm 0,03$ & \\
\hline $\begin{array}{c}\text { Dosis } \\
180 \mathrm{mg} / \mathrm{kg} \mathrm{BB}\end{array}$ & $0,03 \pm 0,02$ & \\
\hline
\end{tabular}

Keterangan : p-value $<0,05=$ perbedaan signifikan*

Pengukuran kadar MDA pada kelompok normal untuk mengetahui kadar MDA normal sehingga saat dibandingkan dengan kelompok perlakuan akan diketahui telah terjadi stres oksidatif atau tidak. Saat keadaan normal, peroksida lipid di dalam tubuh masih dapat diatasi oleh antioksidan alami (antioksidan endogen) yaitu katalase, superokside dismutase (SOD) dan glutation peroksidase ${ }^{23,24}$. Jika dibandingkan dengan kelompok negatif, kelompok normal memiliki kadar MDA yang berbeda signifikan. Kelompok negatif memiliki kadar MDA yang tinggi dibandingkan dengan kelompok normal. Kadar MDA yang tinggi disebabkan oleh kelompok negatif merupakan kelompok yang hanya diberi paparan asap rokok tanpa adanya pemberian antioksidan eksogen. Penelitian yang dilakukan Nabel et al. (2013) menunjukkan bahwa kadar MDA pada tikus wistar yang dipapar asap rokok lebih tinggi dibandingkan yang tidak dipapar asap rokok ${ }^{25}$. Penelitian yang dilakukan terhadap manusia juga menunjukkan hal yang sama, Sibel et al. (2011) menyatakan bahwa manusia yang terpapar asap rokok memiliki kadar MDA yang tinggi pada plasma dibandingkan yang tidak terpapar ${ }^{26}$.

Kelompok normal jika dibandingkan dengan kelompok kontrol positif memiliki hasil yang tidak signifikan. Kelompok kontrol positif merupakan kelompok yang diberi paparan asap rokok dan diberi asupan vitamin E. Vitamin E merupakan vitamin yang memiliki nilai evidence based paling baik jika dibandingkan dengan senyawa lain yang berperan sebagai antioksidan untuk menurunkan kadar MDA berdasarkan penelitian yang dilakukan Maria et al. (2003), Ramesh et al. (2007) dan Thirumalai et al. (2010) ${ }^{27,28,29}$. Vitamin E mampu meredam radikal bebas yang dihasilkan asap rokok. Vitamin E sebagai 
antioksidan mampu memutus rantai peroksidasi lemak dengan menyumbangkan ion hidrogen ke dalam reaksi sehingga menurunkan peroksidasi lipid. Mekanisme penurunan peroksidasi lipid diawali dengan peran $\alpha$-tocoferol radikal yang kemudian berubah menjadi $\alpha$-tocoferol peroksidase. Dua $\alpha$ tocoferol radikal akan berubah menjadi $\alpha$-tocoferol dimer yang pada akhirnya membentuk $\alpha$-tocoquinone 30 .

Kelompok perlakuan merupakan kelompok yang diberi paparan asap rokok dan asupan ekstrak etanol daun bawang mekah. Terdapat tiga dosis berbeda yang digunakan. Kelompok normal hanya memiliki kadar MDA yang signifikan lebih rendah dibandingkan kelompok dosis $45 \mathrm{mg} / \mathrm{kg}$ BB. Dosis $45 \mathrm{mg} / \mathrm{kg}$ BB memiliki kadar MDA yang lebih rendah dibandingkan kelompok kontrol negatif, namun tidak berbeda signifikan, sehingga dapat dikatakan bahwa dosis $45 \mathrm{mg} / \mathrm{kg}$ BB belum mampu menurunkan kadar MDA yang bermakna.

Kelompok dosis $90 \mathrm{mg} / \mathrm{kg}$ BB dan dosis $180 \mathrm{mg} / \mathrm{kg}$ BB memiliki kadar MDA yang tidak berbeda signifikan terhadap kelompok normal dan kelompok kontrol positif, namun berbeda signifikan lebih rendah terhadap kelompok kontrol negatif dan dosis $45 \mathrm{mg} / \mathrm{kg}$ BB. Kadar MDA kelompok perlakuan yang lebih kecil dibandingkan kelompok negatif didugakan oleh peran dari senyawa flavonoid dan alkaloid dari ekstrak etanol daun bawang mekah yang diketahui terkandung di dalam ekstrak setelah dilakukannya skrining fitokimia uji tabung. Widya et al. (2013) dalam penelitiannya menyatakan bahwa flavonoid memiliki peran sebagai antioksidan ${ }^{31}$. Penelitian Yanping et al. (2005) dan Rasyid et al. (2012) mangatakan bahwa flavonoid mampu menurunkan kadar MDA dengan signifikan 32,33. Flavonoid merupakan antioksidan eksogen yang telah terbukti dapat mencegah stres oksidatif. Flavonoid dapat bekerja sebagai antioksidan secara langsung maupun tidak langsung. Sebagai antioksidan secara langsung flavonoid mendonorkan ion hidrogen sehingga menetralisir efek toksik dari radikal bebas. Sedangkan sebagai antioksidan tidak langsung dengan meningkatkan ekspresi gen antioksidan endogen. Mekanisme peningkatan ekspresi gen melalui aktivasi nuclear factor erythroid 2 related factor 2 (Nrf2) sehingga terjadi peningkatan ekspresi gen yang berperan dalam sistesis enzim antioksidan endogen ${ }^{34}$.

Peran alkaloid sebagai antioksidan dibuktikan berdasarkan penelitian yang dilakukan Nihal et al. (2010) yang menyatakan bahwa alkaloid memiliki efek sebagai antioksidan ${ }^{35}$. Penelitian lain yang dilakukan oleh Fadila et al. (2007) menyatakan bahwa alkaloid mempunyai aktivitas antioksidan yang kuat sebagai penangkap radikal bebas ${ }^{36}$.
Alkaloid memiliki dua mekanisme perlindungan sebagai antioksidan yaitu melindungi sel dari toksisitas dan kerusakan genetik yang disebabkan oleh oksidan $\mathrm{H}_{2} \mathrm{O}_{2}$ yang kuat ${ }^{37}$.

Hasil analisis kadar MDA yang diperoleh dari tiga dosis ekstrak etanol daun bawang mekah yang digunakan menunjukkan bahwa dosis yang paling efektif adalah dosis $90 \mathrm{mg} / \mathrm{kg}$ BB. Dosis $90 \mathrm{mg} / \mathrm{kg}$ BB mampu menurunkan kadar MDA sehingga tidak berbeda signifikan terhadap kelompok normal dan kelompok kontrol positif.

\section{KESIMPULAN}

Kesimpulan yang diperoleh dari hasil penelitian ini yaitu ekstrak etanol daun E.americana dosis $45 \mathrm{mg} / \mathrm{kg} \mathrm{BB}, 90 \mathrm{mg} / \mathrm{kg}$ BB dan $180 \mathrm{mg} / \mathrm{kg}$ BB dapat mempengaruhi kadar MDA tikus wistar jantan setelah terpapar asap rokok.

\section{DAFTAR PUSTAKA}

1. World Health Organization. WHO Report on the global tobacco epidemic. World Health Organization; 2013.

2. Richard $\mathrm{R}$ Baker. Smoke generation inside a burning cigarette: modifying combustion to develop cigarettes that may be less hazardous to health. Elsevier. 2006. 32(4): 373-385.

3. Leone A, L. Landini JR, O Biadi, A Balbarini. Smoking and cardiovascular system: cellular features of the damage. Curr Pharm Des . 2008. 14(18): 1771-1777.

4. Knight-Lozano, Cynthia A, Christal G Young, David L Burow, Zhao Yong $\mathrm{Hu}$, Dale Uyeminami, Kent E Pinkerton, Harry Ischiropoulos, Scott W Ballinger. Cigarette smoke exposure and hypercholesterolemia increase mitochondrial damage in cardiovascular tissues. Circulation. 2002. 105(7):849-854.

5. Clarkson, Priscilla M, Heather S. Thomson. Antioxidants: What role do they play in physical activity and health. The American Journal of Clinical Nutrition. 2000. 72(2): 637-646.

6. Souza TP, Oliveira PR, Pereira B. Physical exercise and oxidative stress effect of intense physical exercise on urinary chemiluminescence and plasmatic malondialdehyde. Rev Bras Med Esporte . 2005. 11 (1):97-101. 
7. Somwanshi, Sachin D, Mahesh B Madole, Sandeep Ghuge, Mahendra Bikkad, Sachin B Ingle. Effect of cigarette smoking on lipid peroxidation in semen. International Journal of Basic and Applied Medical Sciences. 2013. 3 (2): 289-294.

8. Mulyohadi Ali, Yuyun Yueniwati. Pengaruh paparan asap rokok kretek terhadap peroksidasi lemak dan system proteksi superoksid dismutase hepar tikus wistar. Jurnal Kedokteran Yarsi. 2004. 12 (1) : 085-092.

9. Wulansari D, Chairul. Penapisan aktivitas antioksidan dan beberapa tumbuhan obat indonesia menggunakan radikal 2,2-diphenyl-1 picrylhydrazyl (DPPH). Majalah Obat Tradisional. 2011. 16 (1) 22-25.

10. Nurliani Anni, Santoso Heri Budi, Rusmiati. Efek Antioksidan Ekstrak Bulbus Bawang Dayak (Eleutherine palmifolia) pada Gambaran Histopatologis Paru-paru Tikus yang Dipapar Asap Rokok. Bioscintiae. 2012. 9(1): 60-69.

11. Dina Pratiwi, Sri Wahdaningsih, Isnindar. Uji aktivitas antioksidan daun E.americana (Eleutherine americana Merr.) dengan metode DPPH (2,2-difenil-1-pikrilhidrazil). Traditional Medicine Journal. 2013. 18(1): 9-16.

12. Indri SDBr Serimbing, Isnindar, Iswahyudi. Uji Aktivitas antioksidan fraksi etanol daun E.americana (Eleutherine Americana Merr.) dengan metode DPPH (2,2-difenil-1pikrilhidrazil). Skripsi. 2013. Fakultas Kedokteran Universitas Tanjungpura Pontianak.

13. Departemen Kesehatan Republik Indonesia. Parameter standar umum ekstrak tumbuhan obat. Jakarta: Departemen Kesehatan Republik Indonesia; 2000. Hal 5, 9-12.

14. Alfinda NK, Nanik SA, Mulyadi T, Bambang K. Buku Ajaran Fitokimia. Surabaya: Airlangga University Press; 2008. Hal 19, 48-49.

15. Raaman N. Phytochemical Techniques. New Delhi: Jai Bharat Printing Press; 2006. Hal 2122.

16. Samuel Santos, Valenc A, Katia Da Hora, Paulo Castro, Vera Gonc, Alves Moraes, La'Is Carvalho, Lu'Is Crist 'Ov Ao De Moraes Sobrino Porto. Emphysema and Metalloelastase Expression in Mouse Lung Induced by Cigarette
Smoke. Toxicologic Pathology. 2004. Toxicologic Pathology. 32(3): 351-356.

17. Momuat, Lydia Irma, Meiske S Sangi, Ni Putu Purwati. Pengaruh VCO mengandung ekstrak wortel terhadap peroksida lipid plasma. Jurnal Ilmiah Sains. 2011. 11(2): 296-301.

18. Voigt R. Buku Pelajaran Teknologi Farmasi. Yogyakarta : Gadjah Mada University Press; 1995. Hal 564.

19. Dewi Susanna, Budi H, Hendra F. Penentuan kadar nikotin dalam asap rokok. Makara Kesehatan. 2003. 7(2): 38-41.

20. Van Der Vaart, DS Postma, W Timens, NHT Ten Hacken. Acute effect of cigarette smoke on inflammation oxidative stress : a review. Thorax. 2004. 59: 713-721.

21. Hery Winarsi. Antioksidan Alami dan Radikal Bebas. Yogyakarta: Kanisius. 2007. Hal 53.

22. Yagi K. Free radical in diagnostic medicine. New York: Plenum Pr. 1994.

23. Suryohudoyo P. Oksidan dan Radikal Bebas Jakarta : CV Sagung. 2000. Hal 31-47.

24. Sadikin M. Biokimia Enzim. Jakarta: Widya Medika. 2002. Hal 87-88.

25. Nabel AAM, Auliani'am, Joni K. Garciniamangostana Linn. pericarp extract reduced malondialdehyde (MDA) level in cigarette smoke exposed rats. IRJES. 2013. 2(9): 1-5.

26. Sibel D, Huseyin O, Handan I, Unal E, Oguzhan $\mathrm{S}$, Zehra S. Oxidative stress in the lungs associated with tobacco smoke exposure. Clin Chem Lab Med. 2011. 49(12): 2007-2012.

27. Ramesh, R. Mahesh, V Hazeena Begum. Effect of Sesbania grandiflora on lung antioxidant defense system in cigarette smoke exposed rats. Internasional Journal of Biological Chemistry. 2007. 1(3): 141-148.

28. Maria Francisca Molina, Isabel Sanchez-Reus, Irene I, Juana B. Quercetin, a flavonoid antioxidant, prevent and protect against ethanolinduced oxidative stress in mouse liver. Biol. Pharm. Bull. 2003. 26(10): 1398-1402. 
29. Thirumalai, SV Therasa, EK Elumalai, E David. Effect in vivo of cigarette smoke on lipid peroxidation and antioxidant status in male albino mice. J. Pharm. Sci \& Res. 2010. 2(9): 579-582.

30. Frankel EN. Lipid Oxidation. California: The Oily Press Dundee. 1999.

31. Widya S, Max RJR, Gayatri C. Kandungan Flavonoid dan Kapasitas Antioksidan total ekstrak etanol daun binahong (Anredera cordifolia) Steenis. Pharmacon. 2013. 2(1): 1822.

32. Yanping Z, Yanhua L, Dongzhi W. Hypercholesterolemic effects of a flavonoid-rich extract of Hyper perforatum $L$. in rat fed a cholesterol-rich diet. J Agric Food Chem. 2005. 53: 2462-2466.

33. HN Rasyid, YD Ismiarto, $\mathrm{R}$ Prasetia. The efficacy of flavonoid antioxidant from chocolate bean extract: prevention of myocyte demage cause by reperfusion injury in predominantly anaerobic sports. Malaysian Orthopedic Journal. 2012. 6(3): 3-6.

34. I Wayan S, I Made J. Ekstrak air daun ubi jalar ungu memperbaiki profil lipid dan meningkatkan kadar SOD darah tikus yang diberi makanan tinggi kolestrol. Jurnal Ilmiah Kedokteran. 2012. 43(2): 67-70.

35. Nihal Turkmen Erol, Ferda S, Y Sedat V. Polyphenols, alkaloids and antioxidant activity of different grades Turkish black tea. GIDA. 2010.35(3): 161-168.

36. Fadila Maiza-Benabdesselam, Sabiha K, Khalida B, Mohamed C, Sandrine A, Yves C, Henry M, Dominique LM. Antioxidant activities of alkaloid extracts of two Algerian species of Fumaria : Fumaria capreolata and Fumaria bastardii. Rec. Nat. Prod. 2007. 1: 28-35.

37. Usama Ramadan Abdelmohsen, Matthias S, Eman MO, Tanja S, Stephanie G, Helga S, Ute $\mathrm{H}$. Antioxidant and anti-protease activities of diazepinomicin from the sponge-associated Micromonospora Strain RV115. Mar. Drugs. 2012. 10: 2208-2221. 